\title{
Influence of Insulin-like Growth Factor I (IGF-I) on the survival and the in vitro development of caprine preantral follicles ${ }^{1}$
}

\author{
Sanely L. Costa ${ }^{2 *}$, Eduardo P. Costa ${ }^{2}$, Emílio C.M. Pereira ${ }^{3}$, Laércio A. Benjamin², \\ Marcelo T. Rodrigues ${ }^{4}$, Vívian R.A. Mendes ${ }^{2}$ and Talita F. Silva ${ }^{2}$
}

\begin{abstract}
Costa S.L., Costa E.P., Pereira E.C.M., Benjamin L.A., Rodrigues M.T., Mendes V.R.A. \& Silva T.F. 2014. Influence of Insulin-like Growth Factor I (IGF-I) on the survival and the in vitro development of caprine preantral follicles. Pesquisa Veterinária Brasileira 34(10):10371044. Programa de Pós-Graduação em Ciências Biológicas e da Saúde, Laboratório de Maturação de Ovócitos e Fertilização In Vitro, Universidade Federal de Viçosa, Avenida Peter Henry Rolfs s/n, Campus Universitário, Viçosa, MG 36570-900, Brazil. E-mail: sanelylc@hotmail.com

The aim of this study was to investigate the effects of the insulin-like growth factor-I (IGF-I) on survival, activation (transition from primordial to primary follicles) and growth of caprine preantral follicles cultured in vitro. Fragments of ovarian cortex were cultured for one and seven days in the absence or presence of IGF-I $(0,50$ and $100 \mathrm{ng} / \mathrm{ml})$. The non-cultured and cultured tissues were processed and analyzed by histology and transmission electron microscopy. The culture for one day in a medium with $100 \mathrm{ng} / \mathrm{ml}$ of IGF-I showed $86.7 \%$ of morphologically normal follicles. These results were similar $(\mathrm{P}>0.05)$ to the percentage of normal follicles found in the control (96.7\%). It was also found that this medium increased the percentage of follicular activation (developing follicles) with one day of culture. The oocyte and follicular diameters remained similar to the control by culturing for one day in a medium containing $100 \mathrm{ng} / \mathrm{ml}$ of IGF-I. The ultrastructural analysis did not confirm the integrity of the follicular fragments in a medium containing IGF-I $(100 \mathrm{ng} / \mathrm{ml})$ after one and seven days of culture. In conclusion, this study demonstrated that the addition of $100 \mathrm{ng} / \mathrm{ml}$ of IGF-I in the culture medium enables the development of preantral follicles of goats with one day of culture. However, it is not sufficient to maintain the follicular integrity and the follicular survival rate after seven days of culture.
\end{abstract}

INDEX TERMS: Caprine, culture, preantral follicles, IGF-I, ovary.

RESUMO-- [Influência do Fator de Crescimento Semelhante à Insulina-I (IGF-I) sobre a sobrevivência e o desenvolvimento in vitro de folículos pré-antrais capri-

\footnotetext{
${ }^{1}$ Received on May 19, 2014.

Accepted for publication on August 18, 2014

${ }^{2}$ Programa de Pós-Graduação em Ciências Biológicas e da Saúde, Laboratório de Maturação de Ovócitos e Fertilização In Vitro (Mofiv), Universidade Federal de Viçosa (UFV), Avenida Peter Henry Rolfs s/n, Campus Universitário, Viçosa, MG 36570-900, Brazil. E-mails: epcosta@ufv.br, laércio@ufv.br,vramendes@hotmail.com, talita_fernandes@hotmail.com; *Corresponding author: sanelylc@hotmail.com

${ }^{3}$ Programa de Pós-Graduação da Universidade Estadual Paulista Júlio Mesquita Filho (Unesdp), Departamento de Reprodução Animal e Radiologia Veterinária, Distrito de Rubião Junior s/n, Botucatu, SP 18618-000, Brazil. E-mail: emiliovet2004@hotmail.com

${ }^{4}$ Programa de Pós-Graduação em Ciências Agrárias, Departamento de Zootecnia, UFV, Avenida Peter Henry Rolfs s/n, Campus Universitário, Viçosa, MG 36571-000. E-mail: mtrodrig@ufv.br
}

nos.] 0 objetivo do presente estudo foi investigar os efeitos do fator de crescimento semelhante a insulina-I (IGF-I) na sobrevivência, ativação (transição de folículos primordiais para primários) e crescimento de folículos pré-antrais caprinos cultivados in vitro. Fragmentos de córtex ovariano foram cultivados por um e sete dias na ausência ou presença de IGF-I (0, 50 e $100 \mathrm{ng} / \mathrm{mL})$. Os tecidos não cultivados e cultivados foram processados e analisados por histologia e microscopia eletrônica de transmissão. 0 cultivo por um dia em meio com $100 \mathrm{ng} / \mathrm{mL}$ de IGF-I apresentou $86,7 \%$ de folículos morfologicamente normais. Estes resultados foram semelhantes $(\mathrm{P}>0,05)$ ao percentual de folículos normais encontrados no controle $(96,7 \%)$. Verificou-se ainda que este meio aumentou o percentual de ativação folicular (folículos em desenvolvimento) com um dia de cultivo. Os diâmetros ovocitário e folicular mantiveram-se semelhantes ao controle ao cultivar por um dia em meio contendo $100 \mathrm{ng} /$ 
mL de IGF-I. As análises ultraestruturais não confirmaram a integridade folicular dos fragmentos em meio contendo IGF-I (100 ng/mL) após um e sete dias de cultivo. Em conclusão, esse estudo demonstrou que a adição de $100 \mathrm{ng} / \mathrm{mL}$ de IGF-I no meio de cultivo ativa o desenvolvimento de folículos pré-antrais de caprinos com um dia de cultivo. Entretanto, não é suficiente para manter a integridade folicular e a taxa de sobrevivência folicular após sete dias de cultivo.

TERMOS DE INDEXAÇÃO: Caprino, cultivo, folículos pré-antrais, IGF-I, ovário.

\section{INTRODUCTION}

The mechanisms which control the initiation of follicular development (the activation of primordial follicles) and the time required for their growth and development are still poorly known (Fortune 2003). Therefore, it is necessary to develop an efficient culture system that allows the activation and the development of preantral follicles to later stages of growth (Costa et al. 2013). Furthermore, the in vitro culture may provide a better understanding of the factors involved in folliculogenesis in the initial (preantral) phase. Among these factors, the insulin-like growth factor I (IGF-I) can be highlighted.

Some growth factors involved in the process of preantral follicular growth have already been studied during the in vitro culture. Thus, Armstrong et al. (1998) and Woad et al. (2000) showed the role of IGF-I in the control of follicular growth. The action of IGF-I is controlled by its association with IGF binding proteins (IGFBPs), which can inhibit or facilitate the action of IGF (Monget \& Bondy 2000). The IGF-I acts as an amplifier of the hormonal action of the gonadotropins. This growth factor enhances the binding between the granulosa, theca and interstitial cells (Adashi 1998), assuming a greater effect on follicular development (Monget et al. 2002). The IGF type I receptor (IGF-IR) is expressed in the theca and granulosa cells in preantral and antral follicles of cattle, being the expression in granulosa cells higher in comparison to the theca cells (Armstrog et al. 2000). It occurs also the expression of IGF-IR in the corpus luteum, which is not influenced by the estrous cycle phase (Woad et al. 2000). In cattle and sheep follicles an expression of significant levels of IGF was not found (Perks et al. 1995). However, in goats the mRNA for IGF-I was expressed in all the follicular categories, being the granulosa and the theca cells of antral follicles the main responsible for the IGF-I production in this follicular class (Hastie \& Haresign 2006).

The responsiveness of IGF-I in the follicles has been demonstrated through several in vitro studies. The addition of IGF-I during the in vitro culture maintains the oocyte survival and stimulates the growth of bovine (Gutierrez et al. 2000), human (Louhio et al. 2000) and murine (Zhao et al. 2001) preantral follicles. During the in vitro culture of preantral follicles of mice it was observed a significant increase in the follicular diameter when IGF-I was added to the culture medium, along with FSH. In addition, a synergism between IGF-I and FSH was also observed in the follicular inhibin secretion (Liu et al. 1998). These results support the hypothesis that IGF-I acts in synergy with FSH in indu- cing the development of granulosa cells, by the regulation of the expression of receptors for FSH. Additionally, FSH was described as the hormone that stimulates the increase of IGF-I receptors during the in vitro culture of granulosa cells (Pawshe et al. 1998), suggesting that some FSH effects could be mediated via IGF-I (Adashi et al. 1985). Although IGF-I has a stimulatory effect on follicular growth in the preantral phase, McCaffery et al. (2000) highlighted the importance of its regulatory mechanism, showing that the inadequate exposure of IGF-I in bovine preantral follicles has a negative effect on the oocyte development.

However, very little is known about the involvement of IGF-I in the regulation of preantral follicular development of goats. The present study was designed in order to investigate the possible influence of IGF-I in the culture medium, at different concentrations $(0,50$ and $100 \mathrm{ng} / \mathrm{mL})$, on survival, activation and growth of preantral follicles enclosed in caprine ovarian tissue.

\section{MATERIALS AND METHODS}

The culture medium and other chemicals used in the present study were purchased from Sigma Chemical Co. (St Louis, MO), unless otherwise indicated.

Ovaries. Ovaries $(n=16)$ from eight adult (1-3 years old), non-pregnant mixed breed goats were collected at a local slaughterhouse. The animals were cyclic and in good body condition. Immediately after death of the animals, the ovaries were washed in $70 \%$ alcohol for 10 seconds and then washed again in MEM supplemented with $100 \mu \mathrm{g} / \mathrm{mL}$ penicillin and $100 \mu \mathrm{g} / \mathrm{mL}$ streptomycin. The pairs of ovaries were transported to the laboratory in MEM at $4^{\circ} \mathrm{C}$ within $1 \mathrm{~h}$ postmortem (Chaves et al. 2008).

In vitro culture of ovarian tissue. This study was approved by the Ethics Committee on Animal Use, CEUA-UFV under case $n^{\circ} 45 / 2012$. In the laboratory, the ovarian cortex of each pair of ovaries was divided in to 7 fragments of approximately $3 \times 3 \mathrm{~mm}$ (1 mm thick). One fragment (non-cultured control) was immediately fixed in Carnoy's fluid for $4 \mathrm{~h}$ for histological studies, while a smaller fragment $\left(1 \mathrm{~mm}^{3}\right)$ was randomly collected and subsequently fixed in paraformaldehyde $2 \%$ and glutaraldehyde $2.5 \%$ in sodium cacodylate buffer $0.1 \mathrm{M}$ ( $\mathrm{pH} 7.2$ ) for ultrastructural examination. The other fragments of ovarian cortices were individually in vitro cultured in $1 \mathrm{~mL}$ of culture medium for one or seven days at $39^{\circ} \mathrm{C}$ with $5 \% \mathrm{CO}_{2}$ in air using a 24 -well culture dish. The control medium was MEM supplemented with ITS (insulin $10 \mu \mathrm{g} /$ $\mathrm{mL}$, transferrin $5.5 \mu \mathrm{g} / \mathrm{mL}$ and selenium $5 \mathrm{ng} / \mathrm{mL}$ ), $2 \mathrm{mM}$ glutamine; $2 \mathrm{mM}$ hypoxanthine and $1.25 \mathrm{mg} / \mathrm{mL}$ BSA, called $\alpha$-MEM+. This control medium was tested alone (cultured control) or supplemented with different concentrations $(50,100 \mathrm{ng} / \mathrm{mL}$ day 1,50 and $100 \mathrm{ng} / \mathrm{mL}$ day 7) of IGF-I. All chemicals used in the present study were purchased from Sigma Chemical Co., unless otherwise indicated. Every 2 days, the culture medium was replaced by fresh medium and each treatment was repeated eight times.

Histological evaluation of preantral follicles. After either 1 or 7 days of culture in each media, the ovarian fragments from each treatment, including the fresh control, were fixed individually in Carnoy for $4 \mathrm{~h}$. After fixation, tissues were dehydrated in increasing concentrations of ethanol, clarified with xylene, and embedded in paraffin wax. Serial sections $(7 \mu \mathrm{m})$ were cut, and mounted on a glass slide and stained with Periodic Acid Schiff hematoxylin (PAS staining system, Sigma, Inc., St Louis, MO, USA). Coded anonymized slides were examined using a microscope (Olympus, Japan) under $400 \times$ magnification. 
Preantral follicles were individually classified according to the shape and number of granulosa cell layers around the oocyte: as either primordial, with one layer of flattened granulosa cells; or as developing follicles, which were further classified as intermediate, with one layer of both flattened and cuboidal granulosa cells; primary, with a single layer of cuboidal granulosa cells; or secondary, with two or more layers of cuboidal granulosa cells (Silva et al. 2004). Primordial and developing follicles were individually determined to be morphologically normal when they showed a healthy oocyte (without a pyknotic nucleus) with granulosa cells organized in layers. Otherwise, degenerated follicles were defined as those with a retracted oocyte, with a pyknotic nucleus, or disorganized granulosa cells detached from the basement membrane. Overall, 240 follicles were evaluated for each treatment (each medium and each culture period). The percentages of healthy primordial and developing follicles were calculated on day 0 (fresh control) and after culture in the various media tested. In addition, oocyte and follicular diameters were measured with the aid of an ocular micrometer, using only normal follicles from day 0 and in vitro cultured follicles thereafter. Two perpendicular diameters were recorded for each follicle and the averages for each of these two values were reported as follicle and oocyte diameters, respectively. Care was taken to count each follicle only once (Matos et al. 2007a). Only follicles with a visible oocyte nucleus were evaluated in order to avoid counting the same follicle twice.

Ultrastructural analysis of caprine preantral follicles. For a more in-depth evaluation of follicular morphology after histological analysis, ultrastructural studies were performed on fragments of fresh control tissue and treatment groups that maintained follicular survival and promoted growth after seven days of culture. A portion with a maximum dimension of $1-\mathrm{mm}^{3}$ was cut from each fragment of ovarian tissue and fixed in Karnovsky solution $(2 \%$ paraformaldehyde and $2.5 \%$ glutaraldehyde in $0.1 \mathrm{M}$ sodium cacodylate buffer at $\mathrm{pH}$ 7.2) for $4 \mathrm{~h}$ at room temperature (RT). After three washes in sodium cacodylate buffer, specimens were post-fixed in 1\% osmium tetroxide and in $0.1 \mathrm{M}$ sodium cacodylate buffer for $1 \mathrm{~h}$ at RT. The samples were then dehydrated through a gradient of acetone solutions, and thereafter, they were embedded in Epon 812 resin. Afterwards, semi-thin sections $(3 \mu \mathrm{m})$ were cut, stained with toluidine blue and analyzed by light microscopy at $400 \times$ magnification. Ultra-thin sections $(60-70 \mathrm{~nm})$ were obtained from preantral follicles, which were classified as morphologically normal in semi-thin sections according to the criteria adopted in histology. Subsequently, ultra-thin sections were contrasted with uranyl acetate and lead citrate, and they were examined under an EM 109 Zeiss (EM, Berlin, Germany) transmission electron microscope (TEM). The density and integrity of ooplasmic and granulosa cell organelles as well as vacuolization and membrane integrity were evaluated.

Statistical analysis. The variables were submitted to Normality (Lilliefors) and Homoscedasticity (Cochran) tests and posteriorly to the analysis of variance at a probability of $5 \%$. In case a significance was presented, the Tukey test was carried out (PROC ANOVA; SAS 2002).

\section{RESULTS}

\section{Effect of IGF-I on preantral follicle survival}

The histological analysis showed that in the culture of ovarian cortex fragments normal (Fig.1A-C) and degenerated (Fig.1 D-F) follicles were found. In the degenerated follicles oocytes with cytoplasmic retraction, pyknotic nucleus and disorganized granulosa cells were observed. A total of 1,680 preantral follicles were counted to evaluate the follicular morphology, activation and growth.
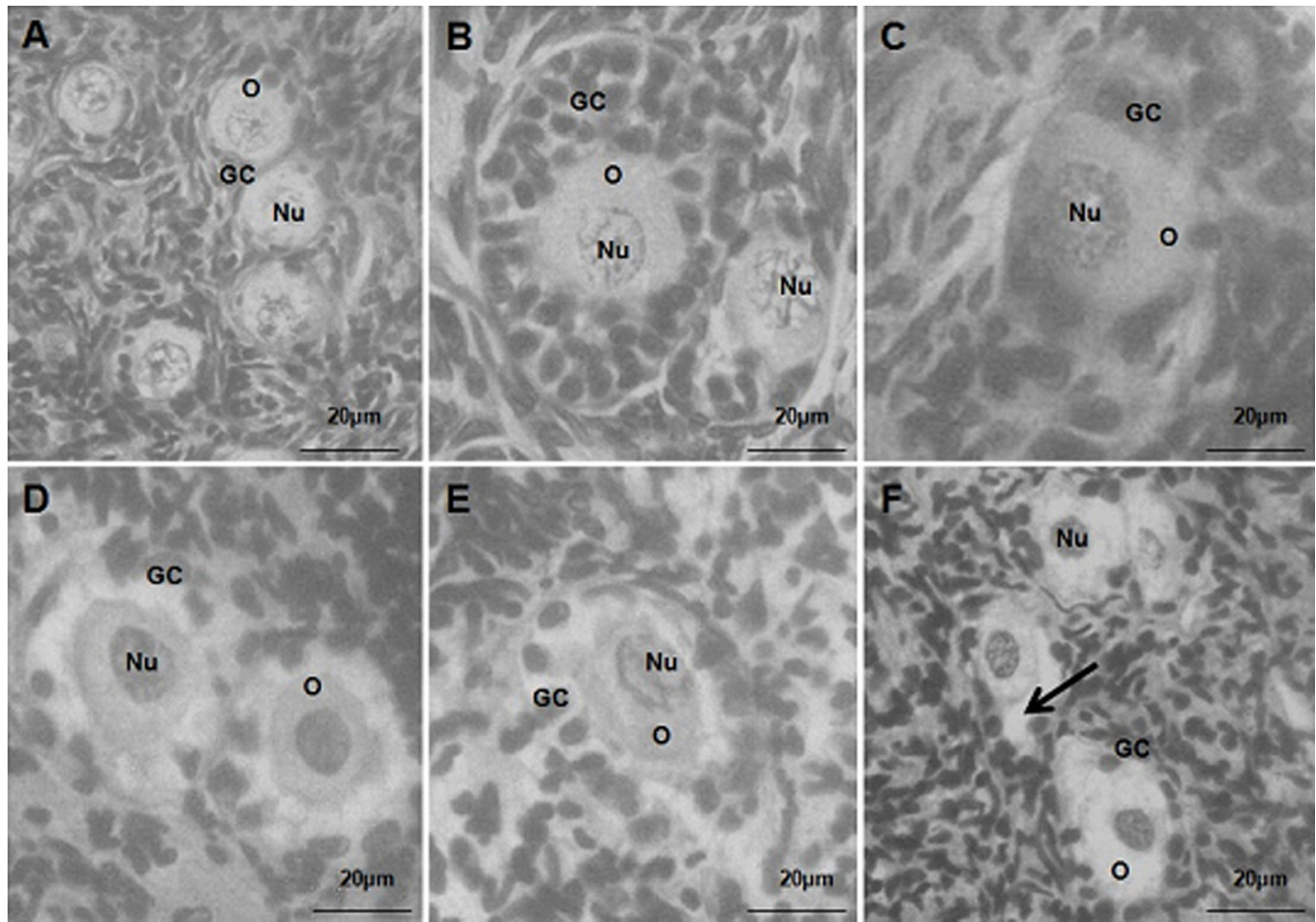

Fig.1. Histological sections of ovarian fragments after Periodic Acid Schiff-hematoxylin staining showing morphologically normal follicles (A, control fresh; $\mathbf{B}$ and $\mathbf{C}$ of 100ng/mL IGF-I after 1 and 7 days of culture respectively) and degenerated (D, $\alpha$-MEM ${ }^{+}$with 1 day of culture; $\mathbf{E}$ and $\mathbf{F}$ of 50ng/mL IGF-I after 1 and 7 days of culture respectivamente). O: oocyte; Nu: oocyte nucleus; GC: granulosa cell (Original magnification $400 \times$ ). arrow-oocyte retracted of granulosa cells. 
Table 1. Percentage (mean \pm SEM) of morphologically normal preantral follicles in the fresh control (non-cultured) and after in vitro culture for 1 or 7 days in the absence or presence of IGF-I (concentrations in $\mathrm{ng} / \mathrm{mL}$ )

\begin{tabular}{lcc}
\hline Control & \multicolumn{2}{c}{$96,7 \pm 0,6$} \\
\cline { 2 - 3 } Treatments & \multicolumn{2}{c}{ Normal } \\
\cline { 2 - 3 }$\alpha$-MEM+ & $67,9 \pm 3,1^{* \mathrm{bA}}$ & $64,2 \pm 6,4^{* \mathrm{aA}}$ \\
IGF-I 50 & $79,6 \pm 3,8^{* \mathrm{aA}}$ & $75,4 \pm 3,2^{* \mathrm{aA}}$ \\
IGF-I 100 & $86,7 \pm 2,0^{\text {aA }}$ & $66,7 \pm 3,1^{* \mathrm{aB}}$
\end{tabular}

*Differs significantly from control follicles $(\mathrm{P}<0.05)$. ${ }^{\mathrm{a}, \mathrm{b}}$ Differs significantly among concentrations in each day of culture $(\mathrm{P}<0.05)$. ${ }^{\mathrm{A}, \mathrm{B}}$ Differs significantly with the progression of the culture period from day 1 to 7 in the same treatment $(\mathrm{P}<0.05)$.

Table 1 shows the percentages of normal follicles in the non-cultured control (D0) and after one and seven days of culture in ovarian cortex fragments in different media. After one day of culture, the addition of $100 \mathrm{ng} / \mathrm{ml}$ of IGF-I maintained the percentage of morphologically normal follicles, when compared to the non-cultured control (86.7\% and $96.7 \%$, respectively, $P>0.05)$. However, a significant reduction in the rate of normal follicles occurred, after the culture in a medium without IGF-I or with $50 \mathrm{ng} / \mathrm{ml}$ $(\mathrm{P}<0.05)$. However, after seven days of culture, none of the media maintained the percentage of normal follicles, when compared to the control.

The addition of IGF-I at both concentrations (50 and $100 \mathrm{ng} / \mathrm{mL})$ enabled a greater percentage $(\mathrm{P}<0.05)$ of normal follicles, after one day of culture, when compared to the cultured control $(\alpha-\mathrm{MEM})$. However, after seven days, the media used behaved similarly $(\mathrm{P}>0.05)$. With the progress of the culture from one to seven days, there was a decrease in the percentage of normal follicles $(\mathrm{P}<0.05)$ using a medium with $100 \mathrm{ng} / \mathrm{ml}$ of IGF-I.

\section{Follicular activation and growth after in vitro culture}

In fresh tissues (non-cultured control), the percentages of primordial and developing follicles were 43.3 and $53.3 \%$, respectively. After seven days of culture, there was a reduction in the percentage of primordial follicles in all treatments (Fig.2A, $\mathrm{P}<0.05$ ) when compared to the fresh control. However, there was not an increase $(P>0.05)$ in the percentage of developing follicles (Fig.2B). After one day of culture, there was a reduction $(\mathrm{P}<0.05)$ in the percentage of developing follicles when cultured in a medium without IGF-I $\left(\alpha-\right.$ MEM $\left.^{+}\right)$.

On day one of cultivation, it was verified that the IGF-I at the concentration of $100 \mathrm{ng} / \mathrm{mL}$ presented a higher percentage $(\mathrm{P}<0.05)$ of developing follicles, when compared to the $\alpha-\mathrm{MEM}^{+}$, demonstrating that there was follicular activation already from the first day of culture, with the use of IGF-I at this concentration.

The follicular and oocyte cell diameter were measured and are presented in Table 2. When compared to the fresh cortical fragments (non-cultured control), both the follicular and the oocyte cell diameters were reduced $(\mathrm{P}<0.05)$ after the culture for one and seven days, except when the follicles were cultured for one day in the presence of $100 \mathrm{ng} / \mathrm{mL}$ IGF-
I. When the $\alpha-\mathrm{MEM}^{+}$(cultured control) was compared to the other treatments ( 50 and $100 \mathrm{ng} / \mathrm{ml}$ of IGF-I), the concentration of $50 \mathrm{ng} / \mathrm{ml}$ IGF-I reduced $(\mathrm{P}<0.05)$ the follicular and oocyte cell diameters, after the culture for one or seven days.
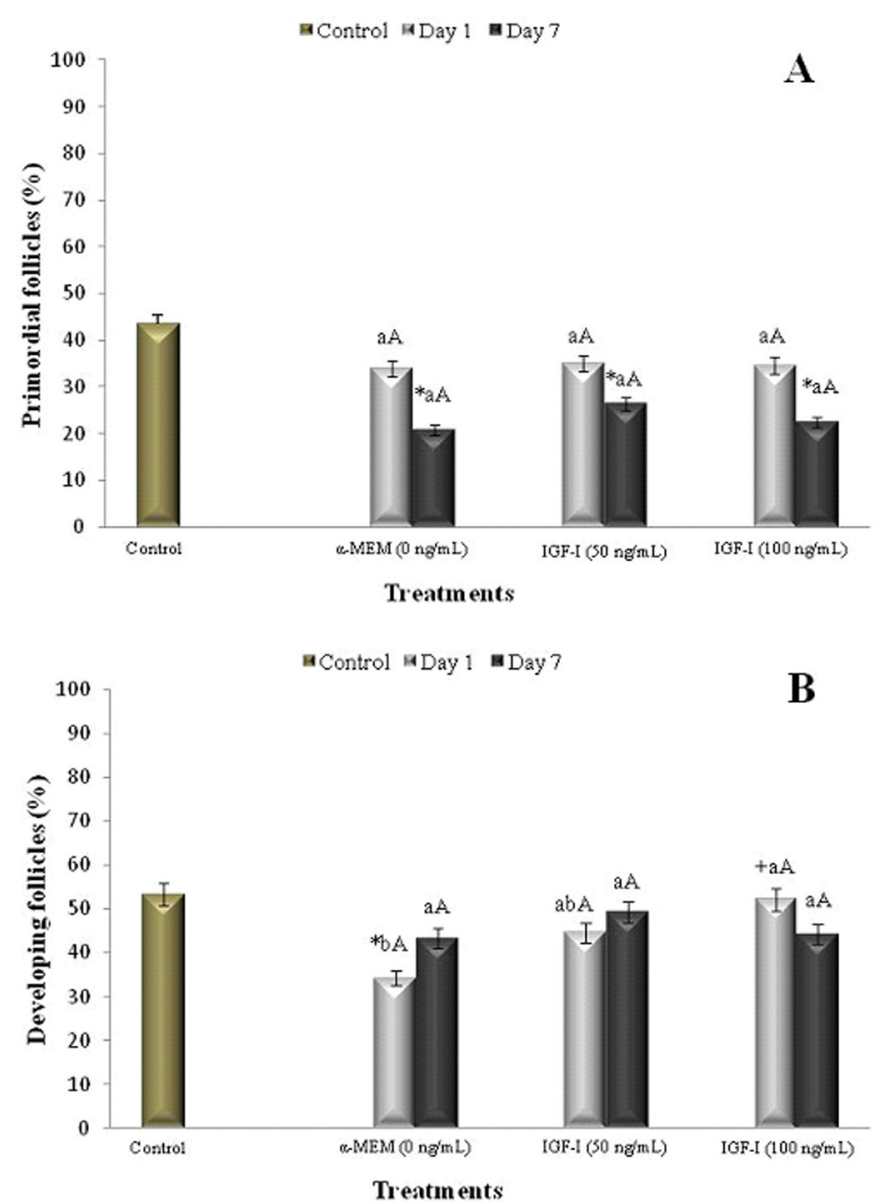

Fig.2. Percentage (mean \pm SEM) of $(\mathbf{A})$ primordial and $(\mathbf{B})$ developing follicles (intermediate, primary and secondary) in noncultured (fresh control) and tissues cultured for 1 or 7 days in the absence or presence of IGF-I (concentrations in $\mathrm{ng} / \mathrm{mL}$ ). ${ }^{*}$ Differs significantly from control follicles $(\mathrm{P}<0.05) ;{ }^{+}$compared with $\alpha-\mathrm{MEM}^{+}(\mathrm{P}<0.05) ;{ }^{\mathrm{a}, \mathrm{b}}$ differs significantly among concentrations in each day of culture $(\mathrm{P}<0.05)$; ${ }^{\mathrm{A} B \mathrm{~B}}$ differs significantly with the progression of the culture period from day 1 to 7 in the same treatment $(\mathrm{P}<0.05)$.

Table 2. Caprine oocyte and follicle diameters (mean \pm SEM) in non-cultured tissues (fresh control) and in tissues cultured for 1 or $\mathbf{7 d a y s}$ in the absence or presence of IGF-I (concentrations in $\mathrm{ng} / \mathrm{mL}$ )

\begin{tabular}{lcccc}
\hline \multirow{2}{*}{ Control } & \multicolumn{2}{c}{ Oocyte diameter $(\mu \mathrm{m})$} & \multicolumn{2}{c}{ Follicle diameter $(\mu \mathrm{m})$} \\
\cline { 2 - 5 } & \multicolumn{2}{c}{$27,4 \pm 0,6$} & \multicolumn{2}{c}{$37,7 \pm 1,1$} \\
\cline { 2 - 5 } & Day 1 & Day 7 & Day 1 & Day 7 \\
\hline -MEM+ & $22,5 \pm 0,9^{* \mathrm{bA}}$ & $22,8 \pm 0,7^{* \mathrm{~A}}$ & $31,2 \pm 1,5^{* \mathrm{bA}}$ & $29,8 \pm 0,9^{* \mathrm{aA}}$ \\
IGF-I 50 & $19,8 \pm 0,5^{* \mathrm{cA}}$ & $19,0 \pm 0,5^{* \mathrm{bA}}$ & $25,7 \pm 0,9^{* \mathrm{cA}}$ & $24,6 \pm 0,7^{* \mathrm{bA}}$ \\
IGF-I 100 & $27,4 \pm 0,8^{\text {aA }}$ & $23,5 \pm 0,5^{* \mathrm{aB}}$ & $37,2 \pm 1,4^{\text {aA }}$ & $30,0 \pm 0,7^{* \mathrm{aB}}$
\end{tabular}

* Differs significantly from control follicles $(\mathrm{P}<0.05)$. ${ }^{\mathrm{a}, \mathrm{b}}$ Differs significantly among concentrations in each day of culture $(\mathrm{P}<0.05)$. ${ }^{\mathrm{A}, \mathrm{B}}$ Differs significantly with the progression of the culture period from day 1 to 7 in the same treatment $(\mathrm{P}<0.05)$. 


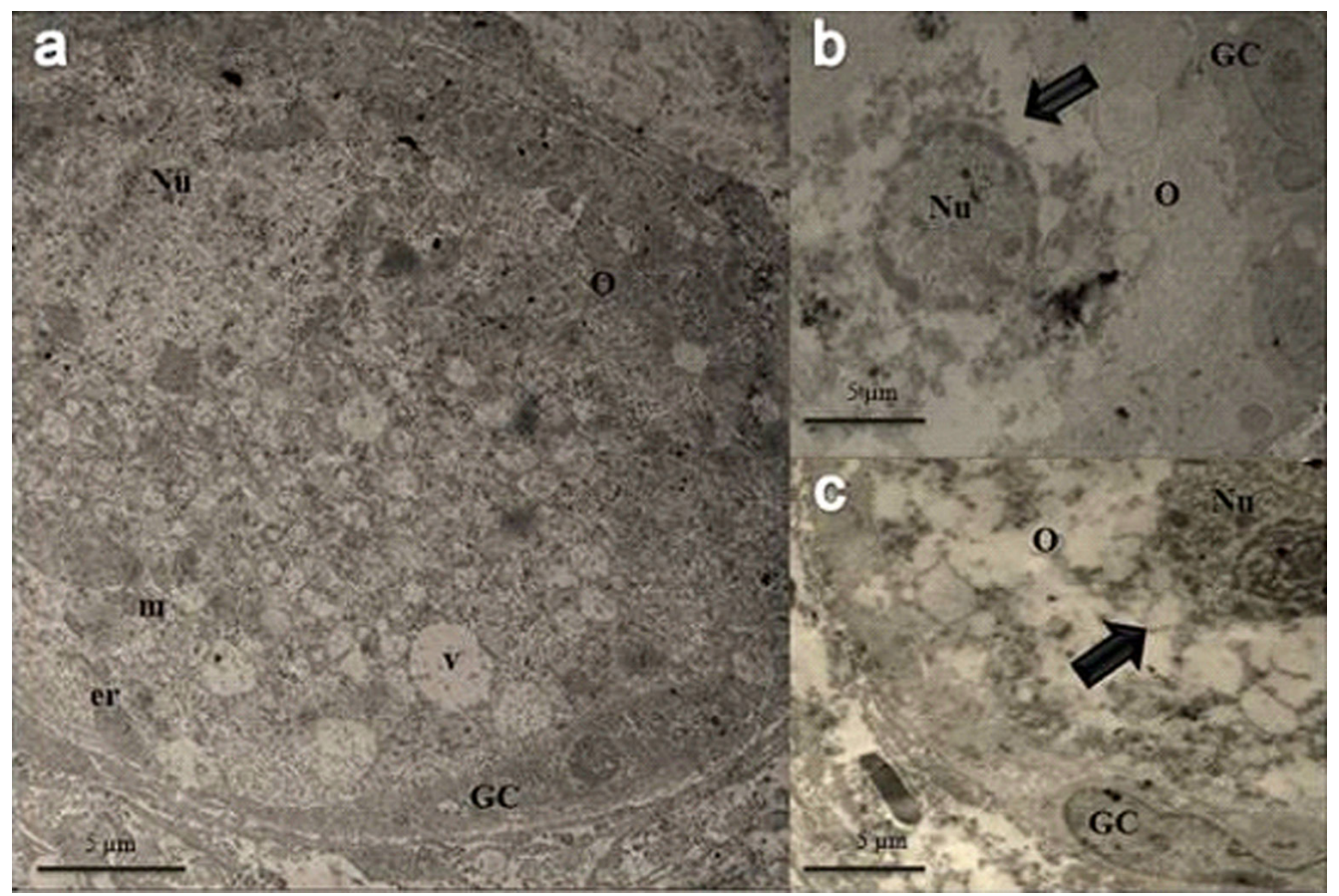

Fig.3. Transmission electron microscopy showing ultrastructure analysis of normal preantral follicles from fresh control (4400x) (a) and cultured for 1 (3000x) (b) and 7 days (3000x) (c) in medium containing like growth factor insulin-I (100ng/mL). Homogeneous cytoplasm and mitochondria rounded is characteristic of non-cultured follicles $(3 \mathrm{a})$. Extreme vacuolization and great holes are present in the cytoplasm, indicative of degeneration (3b and 3c; solid arrow). (Nu) Oocyte nucleus; (GC) Granulosa cells; (m) Mitochondria; (er) Endoplasmic reticulum; (v) Vacuoles.

However, after one day of culture, the concentration of $100 \mathrm{ng} / \mathrm{mL}$ presented higher diameters $(\mathrm{P}<0.05)$ when compared to the $\alpha$-MEM+. When the treatments were compared to each other, the concentration of $50 \mathrm{ng} / \mathrm{ml}$ of IGF-I presented lower diameters $(\mathrm{P}<0.05)$ after one and seven days of culture, when compared to the other treatments. With the progression of the culture from one to seven days, there was a reduction $(\mathrm{P}<0.05)$ in both diameters, in the follicles cultured in a medium with $100 \mathrm{ng} / \mathrm{ml}$ of IGF-I.

\section{Ultrastructural features of cultured follicles}

The ultrastructural analysis was performed in follicles of the control group (non-cultured) and of the group that presented the best results after the in vitro culture (medium with $100 \mathrm{ng} / \mathrm{ml}$ of IGF-I). The Figure 3a illustrates the morphologically normal follicle of the non-cultured control, with the nuclear envelope and cytoplasmic membrane intacts, as well as a small number of vacuoles and various organelles with no signs of degeneration, including mitochondria and endoplasmic reticulum.

Figures $3 \mathrm{~b}$ and $3 \mathrm{c}$ present follicles cultured for one and seven days in a medium containing $100 \mathrm{ng} / \mathrm{ml}$ of IGF-I. IGF-I affected the ultrastructure of the cultured follicles, since evident signs of degeneration were observed. In these follicles, it was observed a large number of vacuoles and a low density of organelles in the cytoplasm. Although the follicles cultured for one day in a medium supplemented with IGF-I were morphologically normal in the histological analysis (optical microscopy), evident ultrastructural signs of degeneration were verified, including irregular retraction of the nuclear envelope and cytoplasmic membrane.

\section{DISCUSSION}

The present study evidenced that IGF-I promotes the survival and development of ovarian follicles of goats during the in vitro culture. Thus, the addition of IGF-I to the culture medium promoted a positive effect on the follicular survival rate in fragments of ovarian tissues cultured for one day. However, none of the concentrations tested in the present study was able to maintain the follicular survival during seven days of culture.

In contrast, other authors reported that the concentration of $100 \mathrm{ng} / \mathrm{ml}$ of IGF-I is able to promote the maintenance of the follicular viability in goats, during nine days of culture (Zhou \& Zhang 2005). Similar results were observed by Martins et al. (2010) who reported that IGF-I, at the concentration of $50 \mathrm{ng} / \mathrm{ml}$, is capable of promoting the follicular viability in the caprine species. Previous studies showed that IGF-I is able to suppress the DNA fragmentation by apoptosis in the follicles of rats cultured in vitro, then acting as an antiapoptotic factor (Chun et al. 1994), beyond mitogenic (Hill 1989). In the present experiment, the media containing IGF-I allowed a greater percentage $(\mathrm{P}<0.05)$ of normal follicles, after one day of culture, when compared to the cultured control ( $\alpha$-MEM). Similar results were observed by Martins et al. (2010) in which the concentrations of 50, 100 and $200 \mathrm{ng} / \mathrm{mL}$ present higher percentages of morphologically normal follicles, when compared to the $\alpha-\mathrm{MEM}^{+}$, after one day of culture. However, the addition of IGF-I in the media was not able to maintain the follicular survival rate after seven days of culture, reducing the percentage of normal follicles, effects also noticed in recent studies (Martins et al. 2010). 
Regarding the follicular activation (that is, the transition from primordial to developing follicles), it was verified that the addition of $100 \mathrm{ng} / \mathrm{ml}$ of IGF-I promoted higher percentages of developing follicles after one day of culture, when compared to the $\alpha-\mathrm{MEM}^{+}$(cultured control). Although treatments did not differ in relation to the percentage of developing follicles at the end of the culture, the use of $100 \mathrm{ng} / \mathrm{ml}$ of IGF-I promoted an early activation, already on the first day of cultivation. Recent studies showed similar results during in vitro culture of ovarian tissue of goat, after one and seven days, using $100 \mathrm{ng} / \mathrm{ml}$ of IGF-I in the medium (Martins et al. 2010). It was verified a reduction in the percentage of primordial follicles after seven days of culture, regardless of the addition or not of IGF-I. Similar results were obtained in previous studies with ovaries of cattle (Wandji, Eppig, Fortune 1996, Braw-Tal \& Youssefi 1997), baboons (Fortune et al. 1998) and goats (Martins et al. 2005, Silva et al. 2006, Matos et al. 2007b, Martins et al. 2008), in which the number of primordial follicles was dramatically reduced with the concomitant increase in the number of developing follicles, after the in vitro culture of ovarian tissue. However, the results of the present experiment differed from other researchers, since there was no increase in the number of developing follicles, after the culture for seven days.

Yang \& Fortune (2002) suggested that high doses of insulin present in the ITS $(3.12$ and $6.25 \mu \mathrm{g} / \mathrm{mL})$, a component added to the culture medium, promotes greater activation of primordial follicles of cattle and increases their survival rate. Although the addition of $100 \mathrm{ng} / \mathrm{ml}$ of IGF-I has promoted greater follicular activation, then decreasing the percentage of primordial follicles on day seven of culture, the culture conditions were not efficient to allow further growth of these activated follicles. This may be due to the absence of pyruvate in the culture medium. This is an organic compound responsible for the production of energy in the form of ATP at the mitochondria level. The more the cell needs energy to perform its vital functions, it will produce more mitochondria. The addition of pyruvate $(0.23 \mathrm{mM})$ to the culture medium has been frequently performed in several researches, with positive results (Araújo et al. 2010, Martins et al. 2010). Studies have demonstrated that the activation of primordial follicles can occur "spontaneously", that is, without the addition of growth factors or hormones (Eppig \& O'Brien 1996). Therefore, the in vitro conditions used nowadays have facilitated the development of follicles from the culture of ovarian tissues, possibly through the release of stimulating factors or preventing the production of inhibitory factors of the oocyte or stroma, granulosa or pre-theca cells, inside the ovarian cortical tissue (Osman et al. 2007). Fortune (2003) confirms in his studies the negative and positive effects of IGF-I, demonstrating that this growth factor has negative effects on bovine primordial follicles and positive effects on secondary follicles in the same species, during follicular activation. Demeestere et al. (2004) observed that the concentrations of 1,10 and $100 \mathrm{ng} / \mathrm{ml}$ of IGF-I did not stimulate the transition from primordial to primary follicles during the in vitro culture of bovine ovarian cortex. Similar results were observed in the present study, when only the primordial follicles were activated, which did not occur in developing follicles.

The culture media tested were not sufficient to promote follicular and oocyte cell growth. However, the culture for one day in a medium with $100 \mathrm{ng} / \mathrm{ml}$ of IGF-I maintained the diameter of oocytes and follicles equivalent to the noncultured control and superior to $\alpha-\mathrm{MEM}^{+}$(cultured control). However, there was a reduction in both diameters, after seven days of culture, regardless of the medium used. These results differ from the results observed by Martins et al. (2010), in which the concentrations of 50 and $100 \mathrm{ng} /$ $\mathrm{ml}$ of IGF-I increased the follicular and oocyte cell diameter after seven of culture, when compared to the non-cultured control. Also Thomas et al. (2007) verified that the addition of $50 \mathrm{ng} / \mathrm{ml}$ of IGF-I during the culture for six days promoted an increase in the follicular diameter in ovarian tissue of cattle. Likewise, Itoh et al. (2002) reported that the addition of $20 \mathrm{ng} / \mathrm{ml}$ of IGF-I to the culture medium increased the follicular and oocyte cell diameter of preantral follicles in cattle. In ovarian tissue of goats, Lorenzo \& Carneiro (2003) found a positive influence of IGF-I on the maturation of oocytes using concentrations above 100ng/ $\mathrm{ml}$ of the medium. In a study using ovaries of prepubescent goats, the concentration of $100 \mathrm{ng} / \mathrm{ml}$ of IGF-I promoted the growth of oocytes enclosed in preantral follicles, after the culture for nine days (Zhou \& Zhang 2005). However, it has already been proved that the use of IGF-I in the culture does not influence the growth of primary and secondary preantral follicles in the cortical tissues of cattle (Derrar et al. 2000) and rats (Liu et al. 1998).

In the present study, the reduction of the follicular and oocyte cell diameter observed during the culture for seven days might have ocurred due to a decrease in the mitosis rate in granulosa cells associated with a reduction in the oocyte size. Another explanation is that two groups of binding proteins for IGF- 1 and 2 growth factors are known, the IGFBP (IGFBP-1, -2, -4 , -5, -6 and the IGFBP-3), which is the form that predominates in serum (Monget et al. 2002, Silva et al. 2008). The mRNA expression of the different proteins has differentiated functions in the follicles of some species, such as IGFBP-2, which decreases during follicular growth in ovaries of sheep, cattle and pigs. On the other hand, the expression of IGFBP-5 mRNA increases in granulosa cells of atretic follicles of cattle and sheep (Zhou et al. 1996). In goats, the protein and the mRNA for IGF-I are expressed in all follicular categories, but the granulosa and theca cells of antral follicles are the main responsible for the production of IGF-I in this follicular category (Silva et al. 2007). The mRNA encoding the IGF-I receptor was detected in oocytes and GCs of antral follicles of cattle. However, this mRNA was not detected in preantral follicles (Armstrong et al. 2002). These results support the hypothesis that IGF-I regulates the growth of follicles through endocrine mechanisms (Armstrong et al. 2002). In this research, the evaluated follicles were preantral (primordial, intermediate, primary and secondary), which is why the addition of IGF-I in the culture medium has not promoted the increase of follicular and oocyte cell diameter, by the seven days of culture. 
The contradictory results of this study with previous studies can be explained by the differentiated sensitivity of each follicle to the treatment used, the species studied, the size of the follicle at the moment of culture, culture time, as the composition of the media used. Arunakumari, Shanmugasundaram, Rao (2010) in one of his researches reports that the differences observed in the IGF-I synthesis pattern during the in vitro culture can influence in the growth of preantral follicles of mice and domestic species. This can be attributed to different action mechanisms and size of preantral follicles (Schams et al. 1999).

Although follicles cultured with $100 \mathrm{ng} / \mathrm{ml}$ of IGF-I have presented similarities with the non-cultured control (rate of non-degenerated follicles) in the examination by light microscopy, evident signs of atresia in transmission electron microscopy were observed. Several studies have emphasized the importance of ultrastructural analysis after the in vitro culture of preantral follicles (cow: Van Den Hurk et al. 1998; mouse: Salehnia et al. 2002, goat: Matos et al. 2007a, Araújo et al. 2010). In the present study, the cultured follicles were characterized by a large number of vacuoles, absence of organelles in the cytoplasm, as well as the nuclear envelope and the cytoplasmic membrane presenting irregularities or fragmentation.

Similar results were observed after the culture of caprine preantral follicles in a medium containing indole3 -acetic acid (Matos et al. 2006). Fortune et al. (2004) reported that the addition of IGF-I to the culture medium increased the atresia of preantral follicles in cattle after the in vitro culture. According to Silva et al. (2006), the apoptosis in primordial follicles cultured in vitro can be induced by the oxygen reduction and the diffusion of nutrients to preantral follicles in the ovarian cortex.

\section{CONLUSION}

The results found in this work permit to conclude that the addition of $100 \mathrm{ng} / \mathrm{ml}$ of IGF-I in the culture medium activates the development of preantral follicles of goats with one day of culture. However, it is not sufficient to maintain the follicular survival rate after seven days of culture.

Acknowledgments.- To CNPq for the financial support to the research. To CAPES for providing the scholarship to the Doctorate student. To the core of Microscopy and Microanalysis of UFV for the support in the ultrastructural analysis.

\section{REFERENCES}

Adashi E.Y., Resnick C.E., D’ercole A.J., Svoboda M.E. \& Wyk J.J.V. 1985. Insulin-like growth factors as intraovarian regulators of granulosa cell growth and function. Endocr. Rev. 6:400-420.

Adashi E.Y. 1998. The IGF family and folliculogenesis. J. Reprod. Immunol. 39:13-19.

Araújo V.R., Silva C.M.G., Magalhães D.M., Silva G.M., Báo S.N., Silva J.R.V., Figueiredo J.R. \& Rodrigues A.P.R. 2010. Effect of Bone Morphogenetic Protein-7 (BMP-7) on in vitro survival of caprine preantral follicles. Pesq. Vet. Bras. 30:305-310.

Armstrong D.G., Baxter G., Gutierrez C.G., Hogg C.O., Glazyrin A.L., Campbell B.K., Bramley T.A. \& Webb R. 1998. Insulin-like growth factor binding protein-2 and -4 messenger ribonucleic acid expression in bovine ovarian follicles: effect of gonadotropins and developmental status. Endocrinology 139:2146-2154.
Armstrong D.G., Gutierrez C.G., Baxter G., Glazyrin A.L., Mann G.E., Woad K.J., Hogg C.O. \& Webb R. 2000. Expression of mRNA encoding IGF-I, IGF-II and type 1 IGF receptor in bovine ovarian follicles. J. Endocrinol. 165:101-113.

Armstrong D.G., Baxter G., Hogg C.O. \& Woad K.J. 2002. Insulin-like growth factor (IGF) system in the oocyte and somatic cells of bovine preantral follicles. Reproduction 123:789-797.

Arunakumari G., Shanmugasundaram N. \& Rao V.H. 2010. Development of morulae from the oocytes of cultured sheep preantral follicles. Theriogenology 74:884-894.

Braw-tal R. \& Yossefi S. 1997. Studies in vivo and in vitro on the initiation of follicle growth in the bovine ovary. Reprod. 109:165-171.

Chaves R.N., Martins F.S., Saraiva M.V., Celestino J.J., Lopes C.A., Correia J.C., Verde I.B., Matos M.H., Báo S.N., Name K.P., Campello C.C., Silva J.R.V. \& Figueiredo J.R. 2008. Chilling ovarian fragments during transportation improves viability and growth of goat preantral follicles cultured in vitro. Reprod. Fertil. Dev. 20:640-647.

Chun S.Y., Billi H., Furuta I., Tsafriri A. \& Hsueh A.J. 1994. Gonadotropin supression of apoptose in cultured preovulatory follilces: mediatory roles of endogenous insulin-like growth factor I. Endocrinology 135:18451853.

Costa S.L., Reis R.S., Ferreira H.C.C., Silveira M.M., Magalhães L.Q. \& Costa E.P. 2013. Cultivo in vitro de folículos pré-antrais. II Congresso Internacional de Agropecuária Sustentável, Viçosa, MG, p.339. (Resumo)

Demeestere I., Gervy C., Centner J., Devreker F., Englert Y. \& Delbaere A. 2004. Effect of insulin-like growth factor-I during preantral follicular culture on steroidogenesis, in vitro oocyte maturation, and embryo development in mice. Biol. Reprod. 70:1664-1669.

Derrar N., Price C.A. \& Sirard M.A. 2000. Effect of growth factors and coculture with ovarian medulla on the activation of primordial follicles in explants of bovine ovarian cortex. Theriogenology 54:587-598.

Eppig J.J. \& O'Brien M.J. 1996. Development in vitro of Mouse Oocytes from Primordial Follicles. Biol. Reprod. 54:197-207.

Fortune J.E., Kito S., Wandji A.S. \& Srsen V. 1998. Activation of bovine and baboon primordial follicles in vitro. Theriogenology 49:441-449.

Fortune J.E. 2003. The early stages of follicular developmennt: activation of primordial follicles and growth of preantral follicles. Anim. Reprod. Sci. 78:135-163.

Fortune J.E., Rivera G.M. \& Yang M.Y. 2004. Follicular development: The role of the follicular microenvironment in selection of the dominant follicle. Anim. Reprod. Sci. 82:109-126.

Gutierrez C.G., Ralph J.H., Telfer E.E., Wilmut I. \& Webb R. 2000. Growth and antrum formation of bovine antral follicles in long-term culture in vitro. Biol. Reprod. 62:1322-1328.

Hastie P.M. \& Haresign W. 2006. A role for LH in the regulation of expression of mRNAs encoding components of the insulin-like growth factor (IGF) system in the ovine corpus luteum. Anim. Reprod. Sci. 96:196-209.

Hill D.J. 1989. Growth factors and their cellular actions. J. Reprod. Fertil. 85:723-734.

Itoh T., Kacchi M., Abe H., Sendai Y. \& Hoshi H. 2002. Growth, antrum formation, and estradiol production of bovine preantral follicles cultured in a serum-free medium. Biol. Reprod. 67:1099-1105.

Liu X., Andoh K., Yokota H., Kobayashi J., Abe Y., Yamada K., Mizunuma H. \& Ibuki Y. 1998. Effects of growth hormone, activin, and follistatin on the development of preantral follicle from immature female mice. Endocrinology 139:2342-2347.

Lorenzo P.L. \& Carneiro G.F. 2003. Biotecnologia e as perspectivas de futuro para caprino-ovinocultura. Anais 2 o Sincorte II Simpósio Internacional sobre Caprinos e Ovinos de Corte, João Pessoa, PB, p.353. (Resumo)

Louhio H., Hovatta O., Sjoberg J. \& Tuuri T. 2000. The effects of insulin, and insulin-like growth factors I and II on human ovarian follicles in longterm culture. Mol. Hum. Reprod. 6:694-698.

Martins F.S., Van den Hurk R., Santos R.R., Silva J.R.V., Matos M.H.T., Celestino J.J.H., Rodrigues A.P.R., Pessoa C., Ferreira F.V.A. \& Figueiredo J.R. 2005. Development of goat primordial follicles after in vitro culture of 
ovarian tissue in minimal essential médium supplemented with coconut water. Anim. Reprod. 2:106-113.

Martins F.S., Celestino J.J.H., Saraiva M.V.A., Matos M.H.T., Bruno J.B., Rocha-Junior C.M.C., Lima-Verde I.B., Lucci C.M., Báo S.N. \& Figueiredo J.R. 2008. Growth and differentiation factor-9 stimulates activation of goat primordial follicles in vitro and their progression to secondary follicles. Reprod. Fert. Develop. 20:916-924.

Martins F.S., Saraiva M.V.A., Celestino J.J.H., Bruno J.B., Almeida A.P., Cunha R.M.S., Silva J.R.V., Campello C.C., Lucci C.M., Matos M.H.T. \& Figueiredo J.R. 2010. Expression of protein and mRNA encoding Insulin Growth Factor-I (IGF-I) in goat ovarian follicles and the influence of IGF-I on in vitro development and survival of caprine preantral follicles. Anim. Reprod. 7:349-361.

Matos M.H.T., Van Den Hurk R., Martins F.S., Santos R.R., Luque M.C.A., Silva J.R.V., Celestino J.J.H., Báo S.N. \& Figueiredo J.R. 2006. Histological and ultrastructural features of caprine preantral follicles after in vitro culture in the presence or absence of indole-3-acetic acid. Anim. Reprod. 3:415-422.

Matos M.H.T., Lima-Verde I.B., Bruno J.B., Lopes C.A.P., Martins F.S., Santos K.D.B., Rocha R.M.P., Silva J.R.V., Báo S.N. \& Figueiredo J.R. 2007a. Follicle Stimulating Hormone and Fibroblast Growth Factor-2 interact and promote goat primordial follicle development in vitro. Reprod. Fert. Develop. 19:677-684.

Matos M.H.T., Lima-Verde I.B., Luque M.C.A., Maia Jr J.E., Silva J.R.V., Celestino J.J.H., Martins F.S., Báo S.N., Lucci C.M. \& Figueiredo J.R. 2007b. Essential role of follicle stimulating hormone in the maintenance of caprine preantral follicle viability in vitro. Zygote 15:173-182.

McCaffery F.H., Leask R., Riley S.C. \& Telfer E.E. 2000. Culture of bovine preantral follicles in a serum-free system: markers for assessment of growth and development. Biol. Reprod. 63:267-273.

Monget P. \& Bondy C. 2000. Importance of the IGF system in early folliculogenesis. Mol. Cell. Endocrinol. 163:89-93.

Monget P., Fabre S., Mulsant P., Lecerf F., Elsen J.M., Mazerbourg S., Pisselet C. \& Monniaux D. 2002. Regulation of ovarian folliculogenesis by IGF and BMP system in domestic animals. Domest. Anim. Endocrin. 23:139-154.

Osman V.P., Anilkumar B., James J.I., Paul M.C., Patrick L. \& George W.S. 2007. Functional genomics studies of oocyte competence: evidence that reduced transcript abundance for follistatin is associated with poor developmental competence of bovine oocytes. Reproduction 133:95-106.

Pawshe C.H., Appa Rao K.B.C. \& Totey S.M. 1998. Effect of insulin-like growth factor I and its interaction with gonadotropins on in vitro maturation and embryonic development, cell proliferation, and biosynthetic activity of cumulus-oocyte complexes and granulosa cells in buffalo. Mol. Reprod. Dev. 49:277-285.

Perks C.M., Denning-Kendall P.A., Gilmour R.S. \& Wathes D.C. 1995. Localization of messenger ribonucleic acids for insulin-like growth factor I (IGF-I), IGF-II and the type 1 IGF receptor in the ovine ovary throughout the estrous cycle. Endocrinology 136:5266-5273.
Salehnia M., Moghadam E.A. \& Velojerdi M.R. 2002. Ultrastructure of follicles after vitrification of mouse ovarian tissue. Fertil. Steril. 78:644-45.

SAS 2002. SAS/STAT ${ }^{\circledR} 9.0$ User's Guide. SAS Institute Inc., Cary, NC.

Schams D., Berisha B., Kosmann M., Einspanier R. \& Amselgruber W.M. 1999. Possible role of growth hormone, IGFs, and IGF-binding proteins in the regulation of ovarian function in large farm animals. Domest. Anim. Endocrin. 17:279-85.

Silva J.R.V., Van Den Hurk R., Matos M.H., Santos T.M., Pessoa R.R., Moraes C.M.O. \& Figueiredo J.R. 2004. Influences of FSH and EGF on primordial follicles during in vitro culture of caprine ovarian cortical tissue. Theriogenology 61:1691-1704.

Silva J.R.V., Tharasanit T., Taverne M.A.M., Van der Weijden G.C., Santos R.R., Figueiredo J.R. \& Van den Hurk R. 2006. The activin-follistatin system and in vitro early follicle development in goats. J. Endocrinol. 189:113-125.

Silva J.R.V., Brito I.R., Leitão C.C.F., Silva A.W.B., Passos M.J., Fernandes L.A., Vasconcelos G.L. \& Figueiredo J.R. 2007. Expressão da proteína morfogenética óssea-6 (BMP-6) em folículos ovarianos caprinos. Resumos da XXI Reunião Anual da SBTE, Costa do Sauípe, BA, p.1044.

Silva J.R.V., Brito I.R., Leitão C.C.F., Silva A.W.B., Passos M.J., Vasconcelos G.L., Saraiva M.V.A., Almeida A.P. \& Figueiredo J.R. 2008. Quantificação da proteína e do RNA mensageiro para o fator de crescimento semelhante à insulina- 1 (IGF-1) em folículos ovarianos caprinos. Resumos XXII Reunião Anual da SBTE, Guarujá, SP, p.466.

Thomas F.H., Campbell B.K., Armstrong D.G. \& Telfer E.E. 2007. Effects of IGF-I bioavailability on bovine preantral follicular development in vitro. Reproduction 133:1121-1128.

Van Den Hurk R., Spek E.R., Hage W.J., Fair T., Ralph J.H. \& Schotanus K. 1998. Ultrastructure and viability of isolated bovine preantral follicles. Hum.Reprod. 4:833-841.

Wandji S.A., Eppig J.J. \& Fortune J.E. 1996. FSH and Growth Factor Affect the Growth and Endocrine Function in vitro of Granulosa Cells of Bovine Preantral Follicles. Theriogenology 45:817-832.

Woad K.J., Baxter G., Hogg C.O., Bramley T.A., Webb R. \& Armstrong D.G. 2000. Expression of mRNA encoding insulin-like growth factors I and II and type 1 IGF receptor in the bovine corpus luteum at defined stages of the oestrous cycle. J. Reprod. Fertil. 120:293-302.

Yang M.Y. \& Fortune J.E. 2002. Insulin and insulin-like growth factor I exert opposite effects on the activation of bovine primordial follicles in vitro. Biol. Reprod. 66:111.

Zhao J., Tavene M.A.M., Van D., Weijden G.C., Bevers M.M. \& Van D.H.R. 2001. Insulin-like growth factor-I (IGF-I) stimulates the development of cultured rat pre-antral follicles. Mol. Reprod. Dev. 58:287-296.

Zhou J., Adesanya O.O., Vatzias G., Hammond J.M. \& Bondy C.A. 1996. Selective expression of insulin-like growth factor system components during porcine ovary follicular selection. Endocrinology 137:4893-4901.

Zhou H. \& Zhang Y. 2005. Effect of growth factors on in vitro development of caprine preantral follicle oocytes. Anim. Reprod. Sci. 90:265-272. 